\title{
Population expansion of some bird species in the city of Wroclaw
}

Grzegorz Kopij

Population expansion of some bird species in the city of Wrocław. - Acta Mus. Siles. Sci. Natur. 65: 229-233, 2016.

\begin{abstract}
During the years 2002-2010, distribution and numbers of eight bird species were studied in the whole city of Wrocław, SW Poland $\left(293 \mathrm{~km}^{2}\right)$. The estimation for these species are as follow: Streptopelia turtur: 3 breeding pairs, Upupa epops: 1, Cuculus canorus: 49, Emberiza hortulana: 7, Luscinia megarhynchos: 214-286, Phoenicurus phoenicurus: 87-118, Turdus pilaris: 105-150, Hippolais icterina: 136-181. In comparison with 1980's and 1990's, a rapid increase in the numbers P. phoenicurus, and T. pilaris, and a slight increase of L. megarhynchos and Cuculus canorus were documented. T. pilaris began to breed in the city in the end of 1990's. The increase may indicate that the habitats in Wrockaw improved both in regard to food availability, nesting sites and other environmental requisitions. The increase in the numbers recorded for $C$. canorus, P. phoe-nicurus, and $L$. megarhynchos may also be a result of good conditions prevailing in their wintering grounds in sub-Saharan Africa.
\end{abstract}

Key words: urban ornithology, population trends, Cuculus canorus, Luscinia megarhynchos Phoenicurus phoenicurus, Turdus pilaris, Hippolais icterina.

\section{Introduction}

Urbanized habitats are regarded as ones of the most rapidly changing habitats in the world (Dunn \& Weston 2008; Kalcey \& Rheinwald 2005). Birds commonly occurring in such habitats are suitable objects to study directions and mechanism of those changes. However, not all bird species are sensitive to environmental changes. Species, such as the Buzzard Buteo buteo, Cuckoo Cuculus canorus, Red-backed Shrike Lanius collurio, Garden Warbler Sylvia borin or Marsh Tit Parus palustris can be used as indicators of the degree of naturalness of some habitats within cities. Others, such as the Robin Erithacus rubecula, Nightingale Luscinia megarhynchos, or Wood Warbler Phylloscopus sibilatrix may be very sensitive to some, even small changes in their habitats (removal of undergrowth and litter). A number of bird species may benefit from human activities (e.g. food, nesting sites). In this study, eight bird species were selected, which numbers were suspected to have increased over the last few decades. An attempt was made in this study, therefore, to estimate the numbers and compare them to those from the past.

\section{Study area}

The city of Wrockaw (SW Poland) within its administrative boundaries has a surface area of $293 \mathrm{~km}^{2}$, and the human population of c. 640000 (in 2004). The city is situated in the large Odra Valley, where four other smaller rivers (Oława, Ślęża, Bystrzyca and Widawa) join the Odra river. There are lots of grasslands along these rivers.

In 2004, arable land comprised $44.8 \%$ of the total surface area, whereas $5.6 \%$ were covered by forests and wooded areas, $3.4 \%$ by water, $9.8 \%$ by roads, $18.7 \%$ by built-up areas, $3.7 \%$ by gardens, $6.1 \%$ by recreational areas, $6.6 \%$ meadows and wetlands, and $1.3 \%$ by wastelands (data from the city government). Marshlands and meadows comprise together $6.6 \%$ (Smolnicki \& Szykasiuk 2002).

The climate of Wroclaw is temperate, slightly warmer than the neighbouring areas. The mean annual temperature is $9.7^{\circ} \mathrm{C}$, with the monthly mean of the coldest month (January) $-0.5^{\circ} \mathrm{C}$, and the warmest month (July) $19.9^{\circ} \mathrm{C}$. Mean annual precipitation is $548 \mathrm{~mm}$. Mean annual humidity is $76 \%$. There are on average 158 days with rains per year, and 1670 hours with sunny weather per year. The snow cover lasts on average 35 days per year (Smolnicki \& Szykasiuk 2002; Bryś \& Bryś 2010). 


\section{Methods}

A simplified version of territory mapping method (Bibby et al. 2012) has been employed to plot on maps occupied territories of some less common species associated with forests, parks and other timbered areas as their breeding and feeding habitats. All such habitats within the administrative boundaries of Wrocław were surveyed at least twice in breeding seasons. First survey was carried out in April and May; second in June and July. Different parts of the city were surveyed in different years. Some of them were covered by Kopij (2004, 2005, 2007, 2008, 2010, 2014a, 2014b, 2014c, 2016a, 2016b). The whole area was covered within a period from 2002 to 2010 .

Several passerine species were selected for this study, namely: Turtle Dove Streptopelia turtur, Cuckoo, Hoopoe Upupa epops, Nightingale, Redstart Phoenicurus phoenicurus, Fieldfare Turdus pilaris, Icterine Warbler Hippolais icterina and Ortolan Bunting Emberiza hortulana.

Each seen or heard individual was plotted on the map 1: 10000 . Special attention was paid to simultaneously singing males and birds performing other territorial and/or breeding behaviour. At least two records of such bird at the same site, made in, at least, two-week-interval, were assumed as representing an occupied territory.

Maps were generated to show the distribution of breeding pairs of all species under the study. The distribution is shown on the background of habitats in the city of Wrocław, as to elucidate habitat preferences of particular bird species.

\section{Results and discussion}

The distribution and numbers of eight selected bird species in the city of Wrocław during the years 2002-2010 are shown in Figs 1-8 and Tab. 1. The data are more precise and accurate for the inner part of the city. In some periphery areas (e.g. Zakrzów, Strachowice airport, Muchobór, Ołtaszyn, Jagodno, Widawa, Polanowice), numbers of some species (e.g. Turtle Dove, Nightingale or Ortolan Bunting) could have been underestimated.

Table 1: Number and densities of some bird species in Wrocław during the years 2002-2010.

\begin{tabular}{|l|c|c|}
\hline Species & Number of pairs/territories & Density [pairs/10km $\mathbf{~}$ \\
\hline Turtle Dove & 3 & 0.1 \\
\hline Cuckoo & 49 & 1.7 \\
\hline Hoopoe & 1 & 0.03 \\
\hline Nightingale & $214-286$ & $7.3-9.8$ \\
\hline Redstart & $87-118$ & $3.0-4.0$ \\
\hline Fieldfare & $105-150$ & $3.6-5.1$ \\
\hline Icterine Warbler & $136-181$ & $4.6-6.2$ \\
\hline Ortolan Bunting & 7 & 0.2 \\
\hline
\end{tabular}

The Nightingale occurred along rivers and canals. It avoided the city centre, where only few pairs were recorded on its outskirts (Fig. 4). The highest concentration of breeding pairs was recorded in the south-eastern part of the city. In comparison with data from the 1980's, their numbers in 2002-2010 are slightly higher in Wrocław (Lontkowski 1987; Marszałek 1992; Kopij 2005, 2007, 2010, 2016c).

The Fieldfare started to breed in Wrocław probably in the late 1990's (Kopij 2016c). It occurs characteristically on the outskirts of the inner part of the city, with the largest number in the so called Big Island and around southern outskirts of the inner city. It is still virtually absent in the northern and western part of the city and has not penetrated to the city centre (Fig. 6). The Fieldfare was first recorded as breeding in Silesia in the end of $19^{\text {th }}$ century (Kollibay 1906). It has expanded its numbers over the $20^{\text {th }}$ century, and in the end of that century it began to adopt some urbanized habitats, such as parks and larger tree clumps. It may compete with the well-established urban Blackbird Turdus merula, causing its decline. 

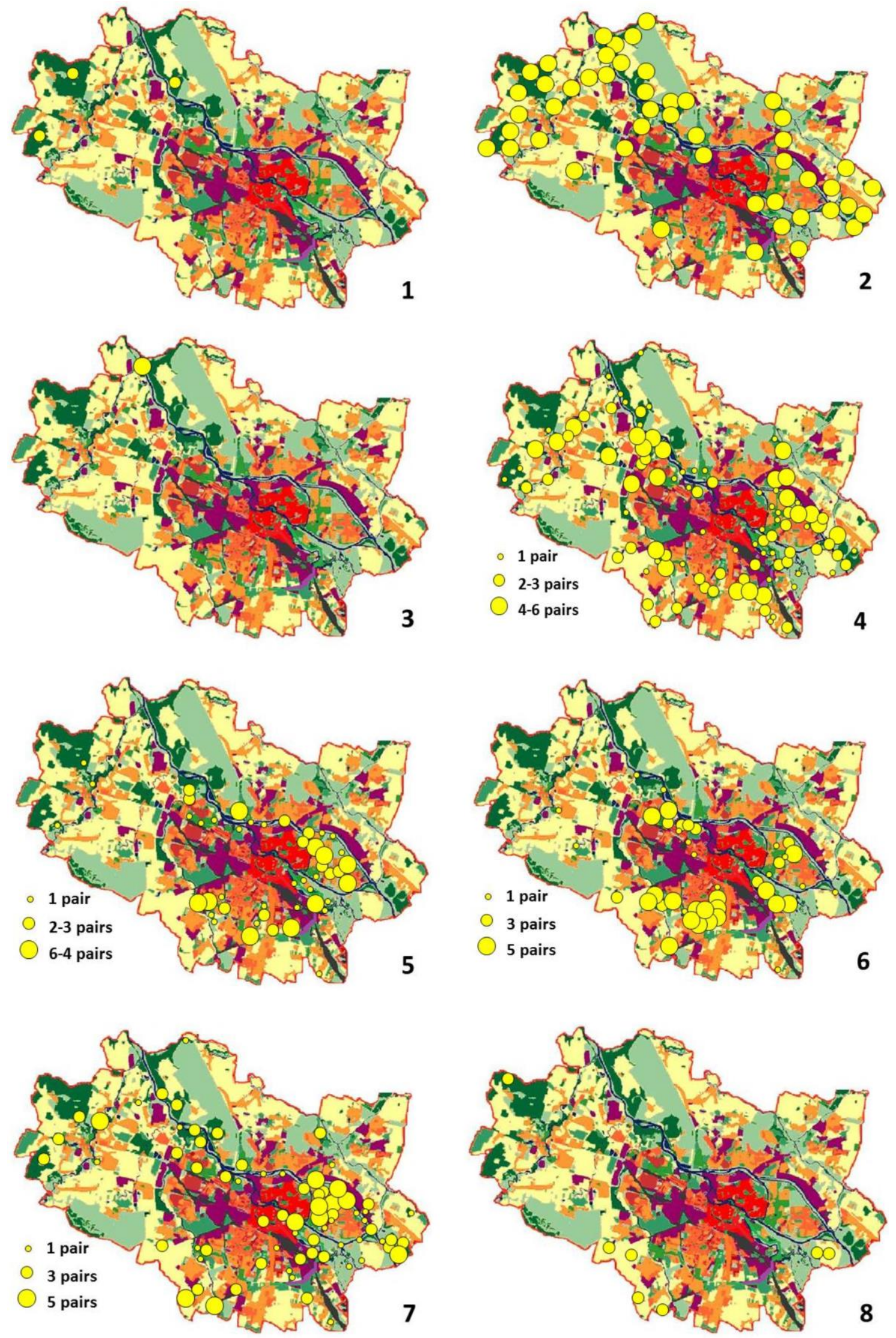

Figs 1-8: Distribution in the city of Wrocław during the years 2002-2010. 1 - Turtle Dove, 2 - Cuckoo male territories, 3 - Hoopoe, 4 - Nightingale, 5 - Redstart, 6 - Fieldfare, 7 - Icterine Warbler, 8 - Ortolan Bunting. [Black - railway, purple - industry areas, red - densely built-up areas, orange - loosely built-up areas, dark green - urbanized woods, light green: parks, seledin - grassy areas, yellow - arable grounds]. 
The Redstart has similar distribution pattern in Wrocław as the Fieldfare. It was common on the outskirts of the inner city, mainly in the allotment gardens and neighbouring parks (Fig. 5). It was, however, rare in the centre and on the periphery of the city, although suitable habitats are available there. While during the years 1978-87, it was virtually absent in Wroclaw (Dyrcz et al. 1991), during the years 2002-2010, 87-118 pairs were recorded (Table 1).

The Icterine Warbler occurred all over the city, with the highest concentration in the south-eastern part. It penetrated even to the city centre (Fig. 7). The Icterine Warbler has disappeared from the urbanized habitats all over Western Europe (Bauer \& Berthold 1997). In the city of Wrocław, it can be still regarded as a common species, which is associated with parks, gardens and small deciduous forests.

For the first time, quantitative data on the number and occurrence of the Cuckoo in the city of Wroclaw are presented (Fig. 2). It can be regarded as indicator for rests of semi-natural habitat (Kopij 2014). The Cuckoo was common in north-western and eastern parts of the city, mainly along rivers and in forests. No data are available on its numbers from the whole city in the past, but data from some smaller areas in the city (Lontkowski et al. 1988; Słychan 1996; Orłowski et al. 2006) suggest an increase of its numbers. This shows that, there are still larger semi-natural areas within the administrative boundaries of Wrocław.

The Turtle Dove and Ortolan Bunting are rare in Wrocław. Only few pairs of each species were recorded during the years 2002-2010 (Fig. 1 and 8). Due to the lack of quantitative data from the past, no trends in their numbers in Wrocław are known.

Only one pair of Hoopoe was recorded in 2002-2010 in Wrocław (Fig. 3). During the years 1978-87, also only one pair was known in the city (Dyrcz et al. 1991). Kopij (2015) has shown, however, substantial increase in the numbers of this species in Silesia in the last two decades. This may, therefore, indicate that the Hoopoe avoids urbanized habitats.

The increase recorded for most of the species studied may indicate that the habitats in Wroclaw improved both in regard to food availability, nesting sites and other environmental requisitions. The increase in the numbers of the Cuckoo, Redstart, Icterine Warbler and Nightingale can also be a result of good conditions prevailing in their wintering grounds in sub-Saharan Africa. It remains, however, uncertain, what are the trends in the number of the Ortolan Bunting, Turtle Dove and Hoopoe in Wroclaw city.

\section{References}

Bauer H.-G. \& Berthold P. (1997): Die Brutvögel Mitteleuropas: Bestand und Gafährdung. Aula-Verlag, Wiesbaden.

Bibby C.J., Burgess N.D. \& Hill D.A. (2012): Bird census techniques. Academic Press, London.

Bryś K. \& Bryś T. (2010): Reconstruction of the 217-year (1791-2007) Wrocław air temperature and precipitation series. - Bull. Geogr. 3: 121-171.

Dyrcz A., Grabiński W., Stawarczyk T. \& Witkowski J. (1991): Ptaki Śląska. Monografia faunistyczna. Uniwersytet Wrocławski, Wrocław.

Dunn A.M. \& Weston M.A. (2008): A review of terrestrial bird atlases of the world and their application. Emu 108: 42-67.

Smolnicki K. \& Szykasiuk M. (eds) (2002): Środowisko Wrocławia. Dolnośląska Fundacja Ekorozwoju, Wrocław.

Kalcey J.G. \& Rheinwald G. (eds) (2005): Birds in European cities. Ginster Verlag, St. Catharinen.

Kollibay P.R. (1906): Die Vögel der preussischen Provinz Schlesien. Breslau.

Kopij G. (2004): Ptaki lęgowe Wielkiej Wyspy Szczytnickiego Zespołu Przyrodniczo-Krajobrazowego we Wrocławiu. - Zesz. nauk. AR Wrocław, Zoot. 50 (488): 187-204.

- (2005): Ptaki lęgowe zachodniej części Śródmieścia we Wrocławiu. - Zesz. nauk. AR Wrocław, Zoot. 53: 8799.

- (2007): Ptaki Starego Miasta we Wrocławiu. - Zesz. nauk. UP Wrocław, Zoot. 55: 93-105. 
- (2008): Awifauna lęgowa Obszaru Specjanej Ochrony Natura 2000 “Grądy Odrzańskie” we Wrocławiu. Parki nar. Rez. Przyr. 27: 95-114.

- (2010): Ptaki lęgowe północno-wschodniej części dzielnicy Fabrycznej we Wrocławiu. - Zesz. nauk. UP Wrocław, Biol. Hod. Zwierz. 60: 77-96.

- (2014a): Ptaki lęgowe klina zieleni w gradiencie urbanizacji na Krzykach we Wrocławiu. In: Indykiewicz P., B ohner J. (eds). Animal, Man and the City - Interactions and Relationships. - Urban Fauna (Bydgoszcz) 6: 195-207.

- (2014b): Breeding bird community of a large cemetery in a Central European city in 1969 and 40 years later. Vogelwelt 135: 67-74.

- (2014c): Population densities of birds breeding in urbanized habitats in the Grabiszyn district in the city of Wrocław. - Acta Musei Silesiae, Sci. Natur. 63: 139-150.

- (2015): Population expansion of the Hoopoe Upupa epops in Silesia, SW Poland. - Rivista Italiana di Ornithologia 85: 38-40.

- (2016a): Breeding avifauna of Niemodlin countryside (SW Poland) during the years 2002-2007, and its changes over the last 56 years (1962-2007). - Acta Mus. Siles., Sci. Natur. 65: 179-192.

- (2016b): Breeding bird assemblage in a mosaic of urbanized habitats in a Central European city. - Vest. Zool. 50(2): 163-172.

Lontkowski J. (1987): Ptaki (Passeriformes) pól irygacyjnych i terenów sąsiednich w północno-zachodniej części Wrocławia (z uwzględnieniem badań ilościowych metodą kartograficzną). - Ptaki Śląska 7: 40-81.

Lontkowski J., Okulewicz J. \& Drazny T. (1988): Ptaki (Non-Passeriformes) pol irygacyjnych i terenów sąsiednich w północno-zachodniej części Wrocławia. - Ptaki Śląska 6: 43-96.

Marszałek M. (1992): Rozmieszczenie i liczebność słowika rdzawego. Praca mag. ZEP UWr., Wrocław.

Orłowski G., Martini K. \& Martini M. (2006): Awifauna południowo-zachodniej części Wrocławia. - Ptaki Śląska 16: 17-70.

Słychan M. (1996): Ptaki pól irygacyjnych Wrocławia. - Ptaki Śląska 11: 133-150.

Author's address: Grzegorz Kopij, Department of Vertebrate Ecology, Wroclaw University of Environmental \& Life Sciences, Kożuchowska 5b, 51-631 Wrocław, Poland. E-mail: grzegorz.kopij@up.wrpc.pl 